\title{
Tekster og sproghandlinger: introduktion til et tema og en problematik
}

\author{
Simon Borchmann
}

Denne artikel er en sprogvidenskabelig introduktion til temaet tekst og sproghandling. Artiklen tjener dels som en beskrivelse af den historiske baggrund for temaet, dels som en argumentation for at det er relevant at behandle en bestemt problematik i relation til dette tema.

Artiklen er delt i to: Først følger en beskrivelse af tekstbegrebets indtog i den moderne sprogvidenskab; dernæst følger en beskrivelse af den dagligsprogsfilosofiske fundering af den sprogvidenskabelige tekstbeskrivelse. Beskrivelsen af denne fundering fokuserer på hvad den teoretisk set indebærer for tekstbeskrivelsen, hvordan den faktisk er tænkt ind i en række hyppigt anvendte tekstbeskrivelser, og hvilken udfordring den repræsenterer for den sprogvidenskabelige tekstbeskrivelse i dag.

Den problematik der argumenteres for en behandling af, er følgende: Hvis vi antager at en sekvens af sætninger er én overordnet sproghandling, hvad er så relationen mellem denne globale sekvensbaserede (makro-)handling og de lokale sætningsbaserede (mikro-)handlinger? Dermed lægges der op til en behandling af denne problematik.

\section{Tekstens indtog i den moderne sprogvidenskab}

\subsection{Udgangspunktet}

Den moderne sprogvidenskab havde ikke i udgangspunktet tekster som genstand. Ifølge Saussure må en videnskab om sprog have langue som genstand, og hvilken forestilling man end må have om tekster, adskiller den sig fra det der hos Saussure forstås ved langue: en teoretisk rekonstruktion af den fælles bevidsthed brugen af sproglige tegn i det sociale liv forudsætter, i form af et selvberoende system af forbindelser mellem lydforestillinger form og begreber (samt visse regler for formning af syntagmer). 


\section{Simon Borchmann}

I henhold til denne tankegang adskiller tekster sig empirisk (og ontologisk) set fra langue i deres egenskab af at foreligge i det sociale liv; de er individuelle manifestationer af langue. Teoretisk set adskiller de sig ved deres kombinationsfrihed: Antag at en sprogbruger S vil skrive en tekst og vil benytte sig af den fælles bevidsthed systemet repræsenterer. Her har $\mathrm{S}$ valgfrihed inden for rammerne af systemet. S kan f.eks. begynde sådan: 'Alt vel'. Det særlige ved tekster er nu at hvis $\mathrm{S}$ vil fortsætte, er der fra en langue-lingvistisk synsvinkel endnu en gang valgfrihed inden for rammerne af systemet; $S$ kan f.eks. vælge 'Tænker på dig' eller 'På snarligt gensyn', men S kan også vælge 'En smuk morgen i maj måned galoperede en elegant amazone på en pragtfuld alezanerhoppe hen ad en blomstrende allé i Boulogneskoven' eller en hvilken som helst - en hvilken som helst! - anden tegnsekvens inden for rammerne af systemet. Der er med andre ord kombinationsfrihed, og det er netop et kendetegn ved parole (Saussure 1970 (1916):156-157). Hvad den fælles bevidsthed - langue - angår, er S imidlertid fuldstændig underkastet de begrænsninger den udgør: For så vidt $S$ vil benytte sig af den fælles bevidsthed, er S nødt til med sine grafiske former at aktualisere lydforestillinger der er forbundet med begreber i den fælles bevidsthed, og endvidere at ordne dem så de aktualiserer syntagmatiske typer opbygget efter regelbundne former.

Man kan nu indvende at de valg tekstskribenten træffer inden for rammerne af systemet, også er underlagt restriktioner: Hvis S skriver i telegramgenren, er der bl.a. en præference for kortformer; hvis ulykkerne hagler ned over hovedet på S, vil S alt andet lige have en større præference for andre valg end alt vel; og hvis $\mathrm{S}$ vælger at indlede med alt vel, vil der desuden være visse restriktioner på fortsættelsen, f.eks. vil gentagelsen af alt vel typisk være unødig. Pointen er imidlertid at sådanne restriktioner hidrører fra tegnenes liv - med alt hvad det indebærer af tekniske, økonomiske, psykologiske, kulturelle og sociale forhold; det er strategier for at aktualisere det potentiale langue repræsenterer, og de har således en anden status end de begrænsninger langue udgør. Tekstlige kombinationsrestriktioner er regulative, sproglige kombinationsrestriktioner er konstitutive.

Inden for de rammer Saussure opstiller, må tekster altså betragtes som parole - tegnenes liv. Det er så tænkeligt at den semiologi Saussure forestillede sig som basis for lingvistikken, studiet af tegnenes liv i det sociale liv, kunne omfatte en disciplin der gjorde tekster, herunder de "livsbestemte" kombinationsrestriktioner de er underkastet, til genstand for systematisk beskrivelse. Men lingvistikken begrænsede sig til langue. 
1.2. Tendenser i tilgangene efter Saussure: strukturalisme, funktionalisme og formalisme

Den mest direkte formulerede sprogvidenskabelige opposition til denne udgrænsning af tekster ser man i begyndelsen af 70'erne med de tekstlingvistiske og tekstgrammatiske programerklæringer. Dem skal vi se nærmere på nedenfor. Her skal vi se på tendenserne i den mellemliggende periode inden for de tilgange den moderne sprogvidenskab udspalter sig i efter Saussure. Det kan nemlig tjene som en nok så informativ perspektivering af tekstlingvistikken samt den kritik den møder.

Inden for den strukturalistiske tilgang finder man - endog fra centralt hold - formuleringer der tilkendegiver en alternativ bestemmelse af genstandsområdet, nemlig hos Hjelmslev i Omkring Sprogteoriens Grundloeggelse. Han skriver:

textanalysen tilfalder lingvisten som en uundgaaelig forpligtelse, ogsaa for de textdeles vedkommende der har større udstrækning. Texten søges delt med selektion og med reciprocitet som inddelingsgrund, og ved hver enkeltinddeling skal der søges de dele som har den største udstrækning. Og det er let at se at en sproglig text af meget stor eller af ubegrænset udstrækning frembyder en mulighed for deling i dele af stor udstrækning ved indbyrdes selektion, solidaritet eller kombination. (1943:88)

Denne forpligtelse kan forstås som en konsekvens af Hjelmslev tekstbegreb og det princip om udtømmende beskrivelse han opererer med. Text er synonymt med forløb hos Hjelmslev, og som endnu ikke analyseret kan et forløb omfatte 'alt hvad der er skrevet og sagt paa dansk' (1943:87); text synes altså at dække over et ideelt korpus. Tanken er så at der bag ethvert forløb er et system, og princippet om udtømmende beskrivelse foreskriver nu at enhver analyse skal registrere det højest mulige antal realiserede funktivkategorier inden for det højst mulige antal funktionskategorier. Det indebærer en inddeling i størrelser der indgår i afhængighedsrelationer, på både udtryksplanet og indholdsplanet, og på hvert af disse planer i både forløb og system. Funktions- og funktivkategorierne er uhyre abstrakte og kan således dække over ikke så lidt:

Idet disse $<$ indholdslinien og udtrykslinien $>$ videredeles hver for sig, vil der blive mulighed og nødvendighed bl.a. for en inddeling inden for indholdslinien i litterære genrer og herunder for 
en inddeling i videnskaberne $\mathrm{i}$ forudsættende (selekterende) og forudsatte (selekterede) (...) På et mere fremskredet trin af proceduren maa de større textdele videredeles i forfatterskaber, værker, kapitler, paragraffer o. lgn. paa basis af deres indbyrdes forudsætningsforbindelser, og dærefter paa samme maade perioderne og sætningerne, hvorved bl.a. slutninger vil blive delt i præmisser og konklusion (1943:88, mit indskud i spidse parenteser)

Hjelmslevs syntagmatik begrænser sig altså så langt fra til det Saussure beskriver som syntagmets idealtype: 'frasen' (Saussure 1970 (1916):156). Når det er konstateret, skal det nævnes at Hjelmslev fremhæver at den fremsatte analyse ikke vedrører den praktiske arbejdsdeling, men emnernes definitoriske betydning. Hjelmslev anser litteraturvidenskab, psykologi, sociologi o.a. for indordnet under sprogteorien. Det er derfor heller ikke klart hvilke konsekvenser analysen i praksis vil have for de lingvistiske discipliners genstandsområde. Men det kan så tilføjes at tekstlingvisten van Dijk så en teoretisk lighed mellem tekstgrammatikken og Hjelmslevs sprogteori (van Dijk 1972:25).

En anden strukturalistisk funderet tendens der er værd at bemærke i denne sammenhæng, er Diderichsens fordring til den syntaktiske beskrivelse. Med udgangspunkt i Saussures skel mellem langue ('Sproget som system') og parole ('Sproget som realisation') og med en henvisning til Ries' definition af sætningen skriver Diderichsen:

naar nemlig Syntaxen opfattes som Læren om Sprogets realisation, maa den Enhed, hvormed den opererer, være den mindste Enhed, der har den realiserede aktuelle Tales Funktion: at bekræfte, benægte eller omspørge Virkeligheden af et udtrykt Forestillingsindhold eller at søge at gøre et vist Forestillingsindhold til Virkelighed. (Diderichsen 1966 (1935):22)

Den funktion der her beskrives, er ikke som hos Hjelmslev en afhængighedsrelation, men - som i de funktionalistiske tilgange - en opgave. Den syntaktiske beskrivelse der stilles fordring om, skal altså tage udgangspunkt i det sproget bruges til, dvs. i ytringen eller sproghandlingen om man vil. Bemærk i øvrigt hvor tæt de beskrevne skel mellem handling og forestilling, og mellem handlingstyper ligger på hhv. Searles analyse af sproghandlingen, $F(p)$, og de grundlæggende relationstyper, direction of fit, Searle funderer sproghandlingstaksonomien på (Searle 1996 (1979)). Selvom beskrivelsen ikke retter sig mod brugen af ytringer, men mod den sproglige enhed den aktualiseres med, dvs. helsæt- 


\section{Tekster og sproghandlinger ...}

ningen, så er det ikke desto mindre ytringens udtryks- og indholdssyntaktiske struktur der skal beskrives. Derfor kan man med en vis ret sige at denne sprogbeskrivelses genstand er ytringen. Det sætningsskema Diderichsen opstiller, danner netop også grundlag for at skelne mellem forskellige illokutionære indikatorer (Heltoft 1999).

Det skal vise sig at tekstlingvisterne - såvel de tidlige som de senere - overser denne pointe; de opererer i stedet med den analytisk afledte teoretiske komponent udsagnet som den basale enhed, og det gør de på både tekstens mikroskopiske og makroskopiske niveau. Det har nogle fatale konsekvenser for tekstlingvistikkens beskrivelsespotentiale og forklaringsværdi. Det vender vi tilbage til.

Diderichsens tilgang adskiller sig desuden fra senere formalistiske tilgange ved antagelsen om at sætningsstrukturen kan og skal afledes af et konkret, historisk tekstmateriale, og at normen med hensyn til arten af sætninger, sætningsforbindelser, sætningsled og underled ville variere fra epoke til epoke, fra dialekt til dialekt og fra stilart til stilart (Diderichsen 1966 (1935):22). I samme forbindelse peger Diderichsen i øvrigt på grammatikken som et grundlag for stilistikken (ibid.). Et forhold han selv udmønter i det storstilede, men ufuldendte projekt Dansk Prosahistorie.

Inden for Pragerskolens funktionalistiske tilgang anerkender man det skel mellem system og anvendelse som er indlejret i Saussures skel mellem langue og parole. Men man er skeptisk over for nogle af de andre skel Saussure forbinder med langue-parole-skellet. Bl.a. kritiserer man beskrivelsen af langue som det sociale og parole som det individuelle, idet man peger på at parole er en social aktivitet. I Pragerskolen anser man sproget for at være et middel; i teserne fra 1929 bliver sproget simpelthen defineret som 'et system af udtryksmidler rettet mod et mål' (Prazský lingvistický krouzek 1929 (kilde Gammelgaard 2003)). Denne antagelse indebærer at sproget ikke kan beskrives i sin helhed uden at inddrage det antagne mål; målet er bestemmende både for hvilke muligheder i tegnsystemet man udnytter og hvordan, og for hvilket tegnsystem man anvender. I overensstemmelse hermed interesserer Pragerskolens funktionalister sig for anvendt sprog, dvs. sprog i konkrete, historiske situationer, herunder ikke mindst tekster.

Blandt de tekstvidenskabeligt relevante arbejder Pragerskolens funktionalistiske tilgang har resulteret i, kan man særligt fremhæve beskrivelsen af sætningens funktion i teksten som meddelelse, dvs. det funktionelle sætningsperspektiv (Mathesius 1975 (1961)). FSP bygger ikke mindst på antagelsen om tekstmeningen som et dynamisk fæno- 


\section{Simon Borchmann}

men, hvorfor sætningen netop må beskrives i sin egenskab af at bidrage til denne dynamik (Firbas 1964 \& 1974, Danes 1974). En anden relevant indsats er beskrivelsen af litterære tekster; den omfatter bl.a. bestemmelser af litterær sprogbrug (Mukarosky 1964 (1939)) og udmønter sig siden i Jakobsons velkendte model over sprogfunktioner (Jakobson 1996 (1960)). Om end enkelte af disse arbejder nævnes i visse af de tekstlingvistiske fremstillinger, glimrer de teoretiske pointer og de specifikke bidrag til beskrivelsen af sætningens tekstuelle funktion ved deres fravær i de tekstlingvistiske programerklæringer.

I den formalistiske tilgang der lanceres af Chomsky i 50'erne, den generative grammatik, er tekster derimod udgrænsede. Den generative grammatiks genstand er den sproglige kompetens (i modsætning til performans) forstået som de regler der genererer, dvs. formelt opregner, mængden af velformerede sætninger. Ud fra denne tankegang er en tekst et overfladefænomen der dækker over de regler, dvs. den sætningsgrammatik, ud fra hvilke man kan generere den givne mængde sætninger. Sætningsgrammatikken genererer dybdestrukturer (initialkonstituent-indikatorer) via basisregler (syntaktiske og leksikalske), og disse transformeres så via transformationelle regler til overfladestrukturer. Denne tankegang indebærer for første at man ikke tager udgangspunkt i den foreliggende sprogbrug (performansen) da produktionen kan være underkastet ikke-ideelle betingelser. De velformethedskriterier man anvender i udformningen af grammatikken, er i stedet funderet på "den indfødte sprogbrugers intuition". I denne forbindelse opererer man med en tese, grammatikalitetstesen, som foreskriver at hvis en rækkefølge af ord bliver regnet for ugrammatisk, må der ligge regler bag. For det andet er den maksimale enhed grammatikken kan generere, altså en sætning. Endelig antager man at grammatikken kan beskrives uafhængigt af semantikken; den begrænser sig med andre ord til udtrykssyntaks. Dermed er tekster helt og aldeles udgrænsede.

Selvom der synes at være paralleller mellem skellet mellem kompetens og performans og skellet mellem langue og parole, adskiller den generative tilgang sig i udgangspunktet radikalt fra den Saussurske ved at antage at sproget er et biologisk fænomen - ikke et socialt. Sætningsgrammatikken antages at være en kognitiv struktur indbygget $\mathrm{i}$ bevidstheden. Og det er, skriver Chomsky i 1976, nytteløst at henvise til vaner og normer når vi skal afgøre i hvilken forstand vi accepterer sproglige regler, og hvorledes vi følger dem. Det at en person accepterer reglerne, må ifølge Chomsky betyde at hun følger de regler der er en del af de kognitive strukturer hendes bevidsthed har skabt (Chomsky 1976). 


\section{Tekster og sproghandlinger ...}

I lyset af de ovennævnte tendenser - ikke mindst de funktionalistiske kan man sige: Hvis man i 70'erne proklamerede at tekster skulle være sprogvidenskabens genstand, kunne man kun dårligt hævde at komme med noget helt nyt. Med mindre man da gjorde det inden for den formalistiske, generative tilgang. Men det var netop også med udgangspunkt i denne at tekstlingvisterne lancerede deres program som et afgørende nybrud.

\subsection{De tekstlingvistiske programerkloeringer}

I begyndelsen af 1970'erne lanceres en række sprogvidenskabelige programerklæringer med teksten som omdrejningspunkt. Under overskrifterne tekstgrammatik (van Dijk 1972) eller tekstlingvistik (Enkvist 1974) foreslår man en ny sprogvidenskabelig disciplin med tekster som genstand. På dette tidspunkt dominerer det generative paradigme i den internationale sprogforskning, herunder de sprogvidenskabelige forskningsmiljøer i en række nordeuropæiske lande. Og det har en afgørende betydning for tekstlingvisternes selvforståelse og tankesæt. På den ene side formulerer de sig i opposition til den generative grammatik med fordringen om at sprogbeskrivelsen må overskride sætningsgrænsen, og at den må omfatte semantik. På den anden side ligger de i vid udstrækning i forlængelse af den generative tankegang: således bliver tekstlingvistikken formuleret som en kompetensdisciplin; man fokuserer på velformethedskriterier; og man anvender grammatikalitetstesen således at hvis en indfødt sprogbrugers intuition afviser noget som en tekst, antages det at der ligger regler bag.

Her i Norden kommer denne selvopfattelse og tankegang bl.a. til udtryk hos Enkvist. I en artikel fra 1974 præsenterer han tekstlingvistikken på følgende vis:

Den som kan svenska märker strax att meningssekvensen:

Carolus dog i förrgår. Blåhaken, Luscinia suecica, är en av våra vackraste och bästa sångfåglar av trastsläktet. Jag skall äta lunch med henne i morgon. Den lägger 5-7 blekt grönblå ägg. Ett gäng som en gång utgått ur en förföljd och klämd minoritetsgruoo sitter i dag och kontrollerar politiskt en stadsdel. Den apterades till matarledning för Borgå med omnejd jämte därifrån utgående 20 $\mathrm{kV}$ landsbygsnät. 
består av en serie grammatiskt riktiga och godtagbara meningar, som ändå inte bildar en normal, godtagbar text. Meningarna saknar sammanhang, syftingarna är formellt oriktiga eller absurda till betydelsen. Eftersom vi märker detta, måste vi i vår språkliga kompetens ha förmågan att skilja mellem en sammanhängande text och en följd av icke-sammanhängande, men eljest korrekta meningar. Språkvetenskapens uppgift är att kartlägga allt som indgår i vår språkliga kompetens. Följaktigen måste språkvetenskapen också försöka förklara vad som det är som gör en normal, koherent text sammanhängande. Den hittilsvarande grammatiken har inte givit oss några klart uttalade kriterier för bedömandet av sammanhang mellean meningarna i en normal, välformad text. Därför behöver vi en ny gren av språkvetenskapen som ägnar sig åt detta. Denna gren är textlingvistiken. (Enkvist 1974:173)

Det er nok de færreste sprogvidenskabelige discipliner der kan beskrives og legitimeres så klart, anskueligt og overbevisende på under en halv side. Derfor er der heller ikke noget at sige til at forskningsprogrammet indledningsvist havde en stor appel. Det pegede på nogle oplagte svagheder ved den generative grammatiks begrænsning til udtrykssyntaks; det lovede samtidig at beskrive teksters indholdsstruktur (med det didaktiske potentiale det indebar); og det lovede at gøre det på de samme formalistiske præmisser som den generative grammatik (med den videnskabelige strenghed man dermed kunne påberåbe sig, og med de muligheder for implementering det indebar).

Enkvists præsentation var i øvrigt forbilledlig ved at tage en række forbehold for tekstlingvistikkens beskrivelsespotentiale og forklaringsværdi og ved at pege på nogle af de problemer den i sin vorden stod magtesløs over for, bl.a. pragmatisk anomali. I det følgende afsnit skal vi se på to beskrivelser der ytrede sig med færre forbehold, og som siden har vist at have en stor gennemslagskraft i formidlingsmæssig sammenhæng.

\subsection{Tekstkriterierne i den sprogsystematiske tekstlingvistik}

Det var ikke alle tekstlingvistikker der var formuleret inden for rammerne af det generative tankesæt (f.eks. ikke Halliday \& Hasan 1976), og det viste sig endvidere at nogle af de centrale skikkelser efter ganske få år havde renset den generative terminologi ud af deres beskrivelser (f.eks. van Dijk 1977). For en samlet fremstilling af fremkomsten af en lingvistisk disciplin der har teksten som genstand, kan der derfor være 


\section{Tekster og sproghandlinger ...}

behov for en lidt bredere karakteristik end den ovenfor anførte generativt funderede. Her kan man passende gå tilbage til udgangspunktet. Det der adskiller tekstlingvistikken fra den oprindelige langue-lingvistik, er den antagelse at tekster ikke er kendetegnet ved kombinationsfrihed; det antages mere præcist 1) at kombinationen af sætninger er underlagt konstitutive regler for kombination således at man kan skelne mellem sekvenser af sætninger der udgør tekster, og sekvenser af sætninger der ikke gør, og 2) at disse regler er af sprogsystematisk art. Tekstbeskrivelser der er kendetegnet ved disse to antagelser, kaldes her sprogsystematisk tekstlingvistik (efter Vater 1992).

Blandt de tekstkriterier der formuleres inden for den sprogsystematiske tekstlingvistik, kan man grundlæggende skelne mellem to typer: Den ene type vedrører det globale tekstlige niveau og er hierarkisk orienteret; den anden type vedrører det lokale tekstlige niveau og er lineært orienteret. I det følgende beskrives to termer der er særligt centrale i forhold til hhv. det globale og det lokale tekstkriterium: makrostruktur og kohcesion. Disse termer har endvidere vist sig at have stor gennemslagskraft i formidlingsmæssig sammenhæng. Da man i nyere tekstlingvistiske fremstillinger godt kan få det indtryk at termerne bruges uden skyldig hensyntagen til hvor de stammer fra, og hvad de indebærer, er det desværre nødvendigt at gå lidt i detaljer her. Det må den tekstlingvistisk velorienterede læser bære over med.

De hierarkisk orienterede kriterier er baseret på en hypotese om semantiske enheder der omfatter store dele af tekstens indhold. Disse enheder kalder van Dijk makrostrukturer (macro-structures). Om makrostrukturer skriver van Dijk i 1972:

Although (...) individual semantic representations of sentences cannot be stored in our memory, we are able to interpret the whole text as grammatically (in)coherent. Obviously, in this process there must be rules forming more abstract, more global structures underlying the sequence of sentences. It is with respect to such memorizable macro-structures we can 'measure' the coherence of the individual sentences. (...)

it should be noted that we explicitly claim that macro-structures (and rules) have a strictly linguistic status. They are not merely aspects of performance, e.g. as non-linguistic cognitive strategies. The generation of textually well-formed (coherent) sentences is possible only when underlying macro-structures are postulated (1972:7) 


\section{Simon Borchmann}

There are many reasons for considering this level $<$ a level of more GLOBAL and abstract structures>, in analogy with generative grammar, to the DEEP STRUCTURE OF A TEXT. This textual deep structure (TDS) is supposed to underlie the actual sentence structures and the interrelations between them (1972:130)

our text grammar is supposed to be a formal model for the competence of native speakers.(1972:132)

The production and reception of coherent texts (...) must be accounted for by models for which only a generative grammar can serve as a formal model (1972:134).

Som det fremgår, hævder van Dijk at den generative grammatik må bruges som model for beskrivelsen af tekster. Den term der bruges om sekvensers velformethed, er kohoerent. Om en sekvens af sætninger er kohærent på det globale niveau, beror altså i henhold til denne hypotese på om den realiserer en makrostruktur svarende til den generative grammatiks initial-konstituent-indikatorer.

Som grundlag for postulatet om makrostrukturer bruger van Dijk følgende kognitionspsykologiske observation af Johnson-Laird: Når sprogbrugere skal gengive en tekst ud fra hukommelsen, er det ikke alene sådan at de ikke kan huske de eksakte udtryksformer (dvs. ord og udtrykssyntaks); de gengiver heller ikke indholdet i dets oprindelige form. Det sprogbrugere lagrer i hukommelsen, adskiller sig altså fra teksten som den tager sig ud "på overfladen". Tanken er så i al sin simpelhed at det er makrostrukturen som lagres i hukommelsen. Samtidig er den basis for genereringen af teksten i alle dens mulige, dvs. velformede, overfladeudgaver. Da den formalistiske tilgang van Dijk anvender, fordrer at makrostrukturen skal kunne transformeres til overfladestrukturen, skal disse strukturer være af samme art. Og da teksten som overfladestruktur - i henhold til den semantik van Dijk støtter sig til - betragtes som en række udsagn, antages makrostrukturen at have samme struktur som et udsagn (1972:134). Ved udsagn (proposition) forstår van Dijk i øvrigt udelukkende den logiske form; det kan ikke bruges til at referere.

I beskrivelsen af makrostrukturen henviser van Dijk nu dels til litteraterne Hendricks der betragter en tekst som en idealiseret sætning af typen Subjekt-Verbum-Objekt, og Kristeva der betragter tekststruktur som analog med en prædikat-argument-struktur, dels til en række ligheder mellem de termer der bruges om tekster, og de termer der bruges om sætninger (1972:141-142). I forlængelse heraf beskriver van Dijk 
så makrostrukturen som en prædikat-argument-struktur. Og nærmere end dette kommer van Dijk ikke på en bestemmelse af makrostrukturen i 1972.

I van Dijks værk Text and Context fra 1977 er den generative terminologi så godt som fraværende. Nu er det udelukkende den formelle logik der tjener som terminologisk ramme. Makrostrukturen beskrives her som 'en mængde hierarkisk ordnede udsagn'. Udgangspunktet er stadig at man hvis man lader en tekst passere gennem en sprogbruger og derefter beder vedkommende om at referere teksten, kommer der noget andet og mere kondenseret ud end den oprindelige tekst. Dette mere kondenserede svarer til det van Dijk nu kalder tekstens makroudsagn. Den grundlæggende model af makrostrukturen er altså følgende:

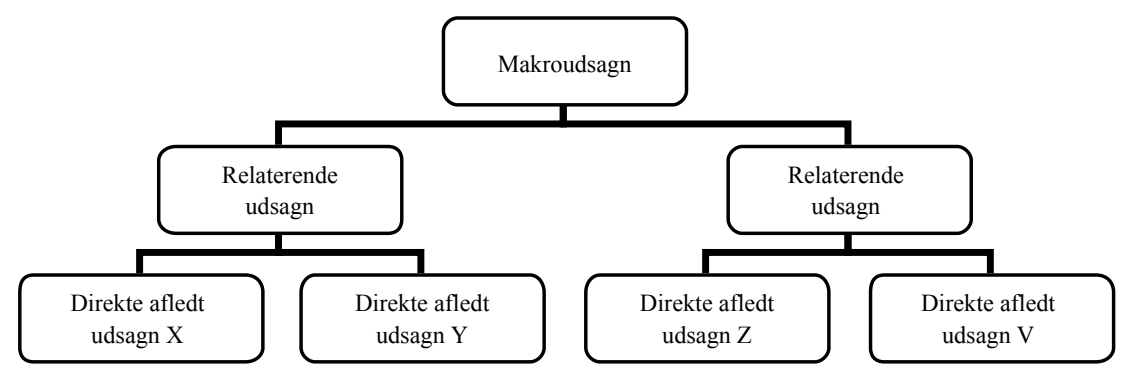

En af de funktioner makrostrukturen tilskrives, er at organisere information i processeringen og hukommelsen. Således antages det at tekstlig information forstået som de udsagn der kan afledes direkte af sætningerne i det lineære forløb, reduceres til makroudsagnet. Det foregår ifølge van Dijk efter følgende fire regler: 1) sletning af tilfældig information, 2) sletning af information der kan afledes af anden information, 3) simpel generalisering og 4) generalisering ved kombination eller integration (1977:143-146). Reglerne svarer til dem man anvender når man skal skrive et referat af en tekst, og ifølge van Dijk er det også sådan sprogbrugere kommer fra overfladeteksten til dybdestrukturen i forståelsen. Det er stadig makrostrukturen der konstituerer kohærensen og dermed teksten; for at en sekvens af sætninger kan regnes for en tekst, skal den altså kunne reduceres til et makroudsagn efter de anførte makroregler.

Van Dijk skriver en passant at der foruden systematiske semantiske relationer selvfølgelig også må indgå viden om verden, men at det må være andre teorier der skal redegøre for denne faktor da det ikke kan være logikkens eller lingvistikkens opgave (1977:51). 


\section{Simon Borchmann}

De lineært orienterede kriterier knytter sig til det sproglige materiale i tilstødende sætninger. Det lineære niveau svarer til det van Dijk i 1972 med den generativt inspirerede term kalder overfladestrukturen (textual surface structure) og som han i 1977 kalder mikrostrukturen (micro structure). En særlig gennemslagskraftig beskrivelse af dette niveau og de hermed forbundne kriterier blev lanceret af Halliday \& Hasan under overskriften kohoesion (cohesion). Om kohæsion skriver Halliday \& Hasan i 1976:

A text has texture, and this is what distinguishes it from something which is not a text. (1976:2)

cohesive ties between sentences stand out more clearly because they are the ONLY source of texture (1976:9)

Cohesion is part of the system of language. (1976:5)

the concept of cohesion accounts for the essential semantic relations whereby any passage of speech or writing is enabled to function as at text. We can systemize this concept by clarifying a small number of distinct categories - reference, substitution, ellipsis, conjunction, and lexical cohesion (...)

Each of these categories is represented in the text by particular features (...) which has in common the property of signalling that the interpretation of the passage in question depends on something else. If that 'something else' is verbally explicit, then there is cohesion. There are, of course, other types of semantic relation associated with a text which are not embodied in this concept; but the one that it does embody is in some ways the most important, since it is common to text of every kind and is, in fact, what makes a text a text. (1976:13)

Blandt de centrale kohæsionskabende midler er reference, substitution og ellipse. Halliday \& Hasan skelner mellem exophoric og endophoric reference. Exophoric (situationel) reference er en relation mellem et udtryk og en referent, f.eks. 'Se solen', der beskrives således at udtrykket 'solen' refererer til solen (situationelt element). Endophoric (tekstuel) reference er en relation mellem et udtryk og et forudgående udtryk, f.eks. 'Se solen. Den går ned nu.', der beskrives således at 'Den' refererer til 'solen', dvs. ordet (tekstuelt element). Dette beskrives som en relation på det semantiske niveau.

Substitution dækker over erstatning af et udtryk med et andet (ved ellipse erstattes udtrykket med intet). De eksemplificerer med følgende: 
Tekster og sproghandlinger ...

1) My axe is to blunt. I must get a sharper one.

2) You think Joan already knows? - I think everybody does.

De beskrives således at 'one' og 'does' er erstatninger; 'one' erstatter 'axe', og 'does' erstatter 'knows'. I henhold til beskrivelsen er det således muligt at udskifte 'one' med 'axe', og 'does' med 'knows'. Kriteriet for substitution er udelukkende at det erstattende udtryk har samme strukturelle funktion som det erstattede. Ovenfor er både 'one' og 'axe' kerne i nominalet, og både 'does' og 'knows' kerne i verbalet. Dette beskrives som en (semantisk) relation på det grammatiske niveau.

Om en sekvens af sætninger danner tekst, beror altså ifølge Halliday \& Hasan på forekomsten af sprogligt materiale der indgår i sådanne relationer på tværs af sætningerne. Det er den 'eneste kilde' til tekstlig sammenhæng.

\subsection{Kritik af den sprogsystematiske tekstlingvistik}

De tekstlingvistiske programerklæringer og beskrivelser møder hurtigt kritik både fra lingvistisk og kognitionspsykologisk hold.

Her i Norden påviser Peter Harder at tekstlingvistikken har et uafklaret forhold til dens grundlag. Som vi har set, bruger tekstlingvisterne dels den generative grammatiks indskrænkning til sætningen til at identificere tekstlingvistikken som disciplin, dels den generative grammatiks grammatikalitetstese til at legitimere det tekstlingvistiske projekt. Spørgsmålet er så om det generative tankesæt kan bruges som grundlag for beskrivelsen af tekster.

Som den vigtigste konsekvens af at tage udgangspunkt i den generative grammatik peger Harder på at tekstlingvistikken opfattes som en kompetensdisciplin. Går man imidlertid til de tekstlingvistiske beskrivelser, viser det sig at de ikke er generative i deres tankegang (der er f.eks. næppe nogen der anser tekster for at være et biologisk fænomen), ligesom mange af deres observationer 'sprænger rammerne for hvad enhver sprogbruger kan sige god for uafhængigt af kontekstuelle hensyn' (Harder 1979:108). Her fremstår tekstlingvistikken altså snarere som en performansdisciplin. Ikke desto mindre beskriver tekstlingvisterne deres observationer som regler enhver tekst er opbygget efter.

Med henvisning til det oprindelige skel mellem langue og parole insisterer Harder på at det sproglige beredskab der med logisk nødvendighed må forudsættes hos sprogbrugere for at de kan opfatte og producere konkrete ytringer, netop er et beredskab som uafhængigt af alle konkrete ytringer fastlægger hvordan man siger hvad. Spørgsmålet er 


\section{Simon Borchmann}

så om dette sproglige beredskab omfatter regler for helheder hvori sætninger indgår som mindre dele, sådan at man kan sige at en tekst - ligesom sætningen - består af et bestemt sæt konstituenter. Ifølge Harder er svaret nej: 'Man kan godt inddele tekster i bestanddele der er større end sætninger; men man kan ikke give regler for deres konkrete sproglige udformning hvis overtrædelse med nødvendighed medfører at teksten bliver ugrammatisk.'(Harder 1979:110). Det illustreres med et af van Dijks egne eksempler på usammenhængende tekst (van Dijk 1972:40):

We will have guests for lunch. Calderon was a great Spanish writer.

Det er, bemærker Harder, ikke sprogbrugerens viden om sproget der dikterer at disse sætninger ikke danner sammenhængende tekst, men sprogbrugerens viden om virkeligheden, nemlig at gæster til frokost og spanske digtere almindeligvis ikke har noget med hinanden at gøre. Og det forhold at man faktisk kan forestille sig en kontekst ${ }^{1}$ hvor de to sætninger danner sammenhængende tekst, taler stærkt for at en afvisning ikke beror på noget uafhængigt af konteksten. Man kan indvende at konteksten er speciel; men hvis man gør det, pådrager man sig samtidig ansvaret for at præcisere hvad der skal til for at en sekvens af sætninger danner tekst. Og indvendingen ændrer heller ikke ved det faktum at man ikke har argumenteret for hvorfor det der umiddelbart forekommer at skabe problemer, skulle være af sproglig art.

Ideen om tekstuel reference som konstitutivt for tekster problematiserer Harder med følgende konstruerede eksempel:

Du kommer til at købe ind i dag. Frederik har forstuvet ankelen og er på skadestuen. Jeg skal have en ny tandbørste. Købmanden lukker først klokken 7.

Her er hverken tekstuel reference eller anden kohæsion²; ikke desto mindre er sammenhængen klar i en bestemt kontekst. Problemet ved ideen om tekstuel reference er at man udelukkende konstaterer at en række sproglige størrelser går igen; man giver ikke en forklaring på hvorfor de gør det. ${ }^{3}$ Harders kritik er ganske vist møntet på Togebys (1979) fremstilling af gentagelsesstruktur som konstitutivt for tekster, men den rammer Halliday \& Hasans ide om kohæsion, herunder tekstuel reference, som tekstkriterium med fuld styrke.

Ifølge Harder indebærer kritikken ikke at man ikke kan generalisere ud over sætningsgrænsen, og heller ikke at man skal afstå fra at opstille strukturer i tekster. Men det betyder at generalisationerne får den 


\section{Tekster og sproghandlinger ...}

karakter som man med langue-begrebet i sin tid forsøgte at komme bag om. Harder hævder at den sproglige viden der går forud for, ikke har større domæne end sætningen. Tekstlingvistikken - eller tekstpragmatikken som Harder foretrækker at kalde den for så vidt som lingvistikken er den videnskab der beskriver sproget som kompetensfænomen - er således en performansdisciplin (Harder 1979). ${ }^{4}$

Harders kritik forekommer indlysende rigtig, og den synes heller ikke at rejse nogen diskussion. Således renser man i løbet af få år fuldstændig ud i den generative terminologi (sammenlign f.eks. van Dijk 1972 og 1977, og Togeby 1979 og 1993), og man begynder i stedet at henvise til andre sprogteorier som grundlag for tekstlingvistikken, ikke mindst netop dem som Harder foreslår som et alternativ. Det skal vi se nærmere på længere nede.

Der bliver imidlertid også peget på fundamentale problemer ved selve generaliseringerne. Således retter Johnson-Laird (hvis kognitionspsykologiske observationer van Dijk bruger som det primære argument for makrostrukturer) en sønderlæmmende kritik mod van Dijks hypotese om makrostrukturer som model for forståelsen (denne hypotese fremsættes i 1978 som en teori (Kintsch \& van Dijk 1978)). Han skriver:

the one major defect of the theory should stand out clearly, namely its reliance on a single propositional format for the representation of both microstructure and macrostructure. The first point at which this format effectively destroys the credibility of the theory concerns co-reference. It simply will not do to assume that if to arguments overlap, they are co-referential. The principle works in the example (...), but there are many cases where it would fail disastrously. The text:

Roland's wife died in 1928. He married again in 1940. His wife now lives in Spain.

Contains two propositions about ROLAND'S WIFE, but despite this overlap in argument, they are obviously not co-referential. This failure of the theory is a symptom of an ultimately fatal debility. The real difficulty is that the two propositional representations that have no overlap in their arguments can nevertheless be co-referential - for instance, the prime minister, Maggie, Mrs 


\section{Simon Borchmann}

Thatcher, and that woman, may all refer to the same individual. A superficial propositional representation is necessary to capture the linguistic form of these descriptions, but it cannot do double duty and represent what they refer to.

Problemet er at den formalistiske tilgang dels fordrer at makrostrukturens relater begrænser sig til udsagn (propositions), dels forhindrer at disse udsagn kan omsættes til et andet format. Det havde ikke været et stort problem hvis modellen var blevet fremsat som en logisk analyse (med det begrænsede potentiale for sprog- og tekstbeskrivelsen den så ville have); men det er det når den fremsættes som en model af forståelsen. Ganske vist tilføjer van Dijk i 1977 en pragmatisk komponent til den logiske, men han hævder af den pragmatiske proces og den logiske, makrostrukturelle proces forløber parallelt. Den makrostrukturelle proces kan imidlertid slet ikke forløbe da løsningen af de skitserede koreferenceproblem fordrer at sætningens udsagnsmæssige indhold fra første færd omsættes til et andet format; der kan således ikke i den løbende forståelse laves de med makrostrukturen postulerede formelle semantiske relationer mellem sætningernes indhold: Det er indhold i to forskellige formater.

Et andet problem ved ideen om makrostrukturen som model for forståelsen er følgende: Hvilke kriterier anvender makroreglerne i den løbende reduktion? Hvordan afgør reglerne hvad der løbende skal bortreduceres, når hverken situationel viden, interesser eller behov er inddraget på det propositionelle niveau? Kintsch \& van Dijk nævner ganske vist skemaer og relevanskriterier i 1978, men hvordan de implementeres i makrostrukturen er uklart (Johnson-Laird 1983:380).

En lige så sønderlæmmende kritik retter Brown \& Yule mod Halliday \& Hasans kohæsionsbegreb. Med følgende eksempel illustrerer de at substitutionsprincippet får absurde konsekvenser (Brown \& Yule 1983:202):

Kill an active, plump chicken. Prepare it for the oven, cut it into four pieces and roast it with thyme I hour.

Den der mener at kunne erstatte 'it' i fjerde sætning med 'an active, plump chicken', kan ikke siges at have forstået teksten (dont do this at home!). Illustrationen er ganske vist komisk, men den viser et alvorligt problem ved selve ideen om kohæsion: Sekvenser af sætninger beskri- 
ves som en i sig selv hvilende sproglig struktur hvor sprogligt materiale $i$ en sætning indgår i relationer med sprogligt materiale $i$ en anden sætning uafhcengigt af en medierende læserpsykologi med alt hvad det indebærer af 1) viden om verden, herunder om madlavning, 2) interesser og behov, herunder for at få noget lækkert at spise, 3) begrænsede hukommelseskapaciteter og selektiv opmærksomhed, 4) evne til at inferere og 5) evne til at konstruere repræsentationer i et ikke-sprogligt format, f.eks. af røg og støj i et køkken. Som Yule \& Brown peger på, kan man hverken forestille sig at sprogbrugere kan huske den eksakte formulering af det oprindelige refererende udtryk, eller at de går tilbage til dette i forståelsen af en efterfølgende tekstintern reference. Opretholdelsen af sådanne koreferenskæder i hukommelsen vil indebære redundans og være særdeles uøkonomisk.

For at løse koreferensproblemet må man i stedet antage at sprogbrugere konstruerer repræsentationer $\mathrm{i}$ et ikke-sprogligt format (hvor simple disse end må være), og at hver sætnings indhold således ikke kobles på den foregående via semantiske relationer, men løbende omsættes til forandringer af repræsentationen. Ud fra disse antagelser henvises der således ikke til 'an active plump chicken' med 'it' i den fjerde sætning, men til repræsentationen af kyllingen der på fokalpunktet for referencen - $\mathrm{i}$ henhold til de foregående sætningers instrukser - har forandret sig fra en levende til en død, plukket, renset og parteret kylling.

Den sprogsystematiske tekstlingvistik led altså ikke blot af en uafklarethed med hensyn til dens grundlag og metode; to af dens mest centrale begreber, makrostruktur og kohæsion, havde fatale skavanker med hensyn til deres beskrivelsespotentiale og forklaringsværdi.

I det følgende afsnit skal vi se på Harders forslag til en alternativ fundering af tekstlingvistikken samt de konsekvenser denne fundering medfører for tekstbeskrivelsens metodik. Senere skal vi vende tilbage til hvilke konsekvenser denne fundering har for hypoteserne om makrostruktur og kohæsion.

\subsection{Alternativet: tekstpragmatikken}

Harders foreslår at flytte tekstbeskrivelsen fra lingvistikken til pragmatikken og fundere den på dagligsprogsfilosofien, herunder sproghandlingsteorien og kommunikationslogikken. Ved denne fundering betragtes teksten som handling, og til rådighed for beskrivelsen står nu handlingsfilosofiens begreber. Harder kan således - med henvisning 


\section{Simon Borchmann}

til Grice og Allwood - sætte den overordnede ramme for tekstbeskrivelsen med det mest grundlæggende træk ved menneskelig handling: formålsbestemtheden. Det kommer til udtryk i følgende som Harder både refererer til som norm og princip (Harder 1979:119):

Enhver menneskelig handling har (skal have) et formål.

Som det udtrykkes med parentesen, har normen en status der både er deskriptiv og normativ; den er deskriptiv i den forstand at vi ikke opfatter noget som en handling hvis det ikke er formålsbestemt; den er normativ i den forstand at vi stiller det krav til hinanden at der skal være et mål med det vi foretager os. Princippet svarer til den antagelse om handlingsrationalitet der beskrives med Grices samarbejdsprincip. Af princippet afleder Harder så tre delnormer der hver beskriver en måde hvorpå teksten kan være forhindret i at realisere et formål.

Formålsprincippet er ikke interessant i sig selv, medgiver Harder, men det er til gengæld de konsekvenser det får for tekstbeskrivelsens metodik. Pointen er at når teksten forstås som et middel til at opnå et overordnet formål, må organiseringen af tekstens dele forstås som bidrag til opnåelsen af dette formål. Tekstens struktur er således dikteret fra oven af en plan der er orienteret mod et bestemt mål, og ikke fra neden af tekstkonstituenter og relationer. Det er konsekvensen af formålssynspunktet. Det er klart at der så også er tale om et andet strukturbegreb end det den traditionelle strukturelle lingvistik opererer med. Tekststruktur er ikke autonom og opererer ikke på lavt niveau ved at bringe komponenter af bestemte kategorier sammen til en mere kompleks enhed.

Harder er opmærksom på det hermeneutiske princip i tekstproduktions- og forståelsesprocessen. Men det berører ifølge Harder ikke det forhold at det afgørende kriterium i processen er helhedens samlede funktion. Struktur er altså ikke noget en tekst får ved at følge abstrakte regler for sammenhæng og orden, men noget den får ved at være strategisk organiseret i forhold til et konkret formål. Det indebærer at man i tekstbeskrivelsen altid arbejder ud fra en forestilling om tekstens formål - og den afklarede tekstanalytiker er bevidst om dette metodiske forhold. ${ }^{5}$

Ideen om at flytte den sprogvidenskabelige tekstbeskrivelse ind under pragmatikken og fundere den på dagligsprogsfilosofien, herunder sproghandlingsteorien og kommunikationslogikken, synes at forekomme rigtig for mange tekstlingvister. Således kan man tale om 
et regulært skifte fra den sprogsystematiske til den pragmatiske eller kommunikativt orienterede tekstlingvistik (se også Vater 1992). Som repræsentanter for den sidste tilgang kan fremhæves de Beaugrande \& Dresslers Introduction to textlinguistics og Brown \& Yules Discourse analysis. Her i Norden kan man fremhæve Ole Togeby som en der netop skifter fra den sprogsystematiske (Togeby 1979) til den pragmatiske tekstlingvistik (Togeby 1993). Af andre nordiske tekstlingvister der i større eller mindre grad funderer deres teoretiske beskrivelser eller formidlinger heraf på sproghandlingsteori og kommunikationslogik, kan nævnes Berge 1986, Bulow-Møller 1989, Vagle et al 1993, Halskov Jensen 2003, Ulbæk 2005, Borchmann 2005.

Harders forslag om en alternativ fundering synes altså heller ikke at kunne give anledning til megen diskussion. Under alle omstændigheder begrænser interessen sig her til sprogvidenskabelige tekstbeskrivelser der er funderet på dagligsprogsfilosofien. Spørgsmålet er så hvilke konsekvenser denne fundering har for tekstbeskrivelsen, herunder for ideer som makrostruktur og kohæsion. Det skal vi se nærmere på i den anden halvdel.

\section{Teksten som sproghandling}

I denne anden del af introduktionen til problemstillingen skal vi se på hvad den dagligsprogsfilosofiske fundering af den sprogvidenskabelige tekstbeskrivelse indebærer. Først skitseres de grundlæggende antagelser i dagligsprogsfilosofien, herunder ganske særligt sproghandlingsteorien og kommunikationslogikken. Derefter beskrives problemer ved sproghandlingsteorien som tekstbeskrivelse. Så følger en skitsering af de konsekvenser den dagligsprogsfilosofiske fundering indebærer for beskrivelsen af sekvenser af sætninger. Endelig skal vi se på hvilke konsekvenser det så faktisk viser sig at have haft for nogle udvalgte tekstlingvistiske beskrivelser. Disse trin danner grundlag for en i beskrivelse af de udfordringer den dagligsprogsfilosofisk funderede sprogvidenskabelige tekstbeskrivelse står over for.

Pointen med fremstillingen er at tekstlingvistikken for en stor dels vedkommende ikke har draget konsekvenserne af den dagligsprogsfilosofiske fundering. Således huserer nogle af den sprogsystematiske tekstlingvistiks mest tvivlsomme hypoteser stadig - med alle de problemer og blokeringer for udnyttelse af sproghandlingsteorien og kommunikationslogikkens muligheder det indebærer. 


\section{Simon Borchmann}

\subsection{Udsagnet - og sproghandlingen}

Den uden sammenligning vigtigste sprogfilosofiske erkendelse i dagligsprogsfilosofien er at meningsproduktionens basis ikke er udsagnet, men ytringen. Ud fra denne erkendelse er udsagnet en teoretisk abstraktion der ikke kan tildeles mening (men måske nok betydning, dvs. indhold i langue-lingvistisk forstand). Det er hovedpointen hos Wittgenstein, det er hovedpointen hos Austin, og det er hovedpointen hos Searle.

Det er desværre nødvendigt at gentage og udpensle denne pointe med citater; for som vi senere skal se, synes det som om den er aldeles glemt $i$ en række sprogvidenskabelige tekstbeskrivelser der angiveligt er funderet på dagligsprogfilosofien. Wittgenstein skriver om udsagnet:

Freges opfattelse, at der i en påstand ligger en antagelse, som er det, der påstås, er egentlig baseret på den mulighed, som findes $i$ vort sprog, at man kan give enhver påstandssætning formen "det påstås, at det og det er tilfældet." - Men "at det og det er tilfældet" er i vort sprog netop ingen sætning - det er endnu ikke et trcek i sprogspillet.(...)

Vi kunne også meget vel give enhver påstand form som et spørgsmål, med efterfølgende bekræftelse; f.eks.: "Regnet det? Ja!". Ville det vise, at der i enhver påstand gemmer sig et spørgsmål?

Man har vel ret til at anvende et assertionstegn i modsætning til f.eks. et spørgsmålstegn; eller til at skelne mellem en påstand og en fiktion eller antagelse. Det bliver kun forkert, når man nu mener, at påstanden nu består af to akter, overvejelsen og hævdelsen (tilskrivelsen af sandhedsværdien, eller lign.), og at vi udfører disse akter efter sætningens tegn, omtrent som vi synger efter noder. Det at læse den skrevne sætning højt eller for sig selv kan man sammenligne med det at synge efter noder, men ikke 'det at mene' (at tænke) den læste sætning.

Freges assertionstegn betoner sætningens begyndelse. Det har altså en lignende funktion som et punktum. Det adskiller sætningen i perioden fra hele perioden. Når jeg hører en eller anden sige "Det regner", uden at vide, om jeg har hørt periodens begyndelse eller slutning, er denne sætning for mig endnu ikke noget middel til forståelse.(Wittgenstein 1995 (1958):43 (§22))

Lad os tænke os et billede som forestiller en bokser i en bestemt kampstilling. Dette billede kan nu bruges til at meddele en eller anden, hvordan han skal stå, hvilken holdning han skal indtage; eller hvilken holdning han ikke skal indtage; eller hvorledes en 


\section{Tekster og sproghandlinger ...}

bestemt mand har stået der og der; eller ect. ect. Man kunne kemisk talt kalde dette billede en sætningsradikal. På lignende måde tænkte Frege sig vel antagelsen. (Wittgenstein 1995 (1958):44 (note til §22-23))

I henhold til Wittgenstein er udsagnet ikke et træk i sprogspillet; som det fremgår, er han endog skeptisk med hensyn til om det overhovedet er en sprogbrugsanalytisk kategori. Og det er det under alle omstændigheder ikke på meningens niveau. End ikke et udsagn fremsat i det påstandsindikerende deklarative skema ('Det regner') anses for et middel til forståelse hvis ikke man ved hvilken sammenhæng skemaet indgår i.

Hos Austin formuleres pointen i forbindelsen med erkendelsen af at skellet mellem konstativer og performativer ikke er et skel mellem talehandlinger, men mellem aspekter af en talehandling:

(a) Med den konstative ytring abstraherer vi fra de illokutionære og i endnu højere grad de perlokutionære aspekter af talehandlingen og koncentrerer os om de lokutionære. Dertil kommer at vi bruger en primitiv forestilling om korrespondens med kendsgerninger - primitiv, fordi det illokutionære aspekt nødvendigvis må inddrages. Det drejer sig om den idealforestilling at der findes noget som det vil være rigtigt at sige uafhængigt af omstændighederne, med et hvilket som helst formål, henvendt til hvem som helst, osv. Måske er det forekommet en sjælden gang at det ideal har været realiseret.

(b) Med den performative ytring koncentrerer vi os så meget som muligt om ytringens illokutionære effekt og abstraherer fra den dimension der hedder korrespondens med kendsgerninger.

Måske er ingen af disse abstraktioner særlig hensigtsmæssige. (...) (Austin 1997 (1962):164-165)

Ifølge Austin er ideen om udsagnet som meningsmæssig enhed altså en idealforestilling. Som sprogbrugsaspekt fordrer det inddragelsen af det illokutionære aspekt, dvs. det handlingsmæssige med alt hvad det indebærer af situationsspecifikke konventioner. Bemærk i øvrigt at også Austin er betænkelig ved analysen.

Endelig er pointen direkte formuleret hos Searle:

the illocutionary act is the mimimal unit of linguistic communication (2001 (1965):80)

An assertion is an illocutionary act, but a proposition is not an 


\section{Simon Borchmann}

act at all, although the act of expressing a proposition is a part of performing certain illocutionary acts.(...)

for a large class of sentences used to perform illocutionary acts, we can say that for the purpose of our analysis that the sentence has two (not necessarily separate) parts, the proposition indicating element and the function indicating device. The function indicating device show how the proposition is to be taken, (2001 (1965):84)

Udsagnet, dvs. en funktion der forbinder et singulært udtryk med et prædikat, er altså ikke en handling i følge Searle. For at kunne tildeles mening må det indgå $i$ en helhed der omfatter en komponent der angiver hvorledes den repræsentation der kan konstrueres ud fra det udsagnsmæssige indhold, skal relateres til situationen. Det er analytisk set de to grundlæggende komponenter i ytringen eller sproghandlingen: en instruktion om repræsentation og en instruktion om hvorledes repræsentationen skal relateres til situationen.

Lad os for den efterfølgende redegørelses skyld se bort fra Austins og ikke mindst Wittgensteins skepsis med hensyn til om udsagnet overhovedet er en sprogbrugsanalytisk kategori. Vi forudsætter således at vi $i$ hvert fald på det abstrakte, betydningsmæssige niveau kan skelne mellem ytringens udsagnsmæssige indhold og den illokutionær indikator.

De tre dagligsprogsfilosoffer er uenige om hvor mange forskellige relationer en repræsentation kan have til en situation; som det antydes med 'ect. ect.' i Wittgenstein-citatet ovenfor, og som det det mere præcist fremgår af i paragraf $23 \S$ om sprogspillene, er der ifølge Wittgenstein mangfoldige, ligesom som nye kan opfindes. Både Austin og Searle er skeptiske over for denne tanke. ${ }^{6}$ De opstiller taksonomier, og ifølge Searle er der netop fire grundlæggende relationer: word-toworld, world-to-word, double direction of fit (word-to-world forårsager - per konvention - world-to-word) og null. Denne uenighed berører imidlertid ikke antagelsen om at den udsagnsmæssige repræsentation først relateres til situationen med den illokutionære indikator.

En anden uenighed vedrører udsagnets tolkningsmæssige afhængighed. Som det fremgår af Wittgenstein- og Austincitaterne, beror fastlæggelsen af udsagnets sandhedsbetingelser såvel af den konkrete situation som af sprogbrugstypen. Vi kan altså ikke opbygge en repræsentation uafhængigt af viden om den konkrete situation og den institutionelle ramme (eller det sprogspil) der muliggør sproghandlingen: Situationen og genren er ganske simpelt forståelsesbetingelser for 
det udsagnsmæssige indhold (man ihukommer sig Austins eksempel 'Frankrig er sekskantet'). I modsætning hertil synes Searle at tilskrive udsagnet et mere selvstændigt indhold; det forbindes ikke alene med et konventionelt indhold, men også med en fastlagt reference (2001 (1965):84). Denne uenighed berør imidlertid heller ikke den fælles antagelse at den udsagnsbaserede repræsentation først relateres til situationen via ytringen som helhed, herunder den illokutionære indikator. Det fremgår endvidere af de betingelser Searle opstiller for den illokutionære handling, at den illokutionære indikator lægger restriktioner på det udsagsmæssige indhold (assertionens illokutionære indikator kan dog tage et hvilket som helst indhold). Fra en dagligsprogsfilosofisk synsvinkel er udsagnet altså $\mathrm{i}$ enhver forstand meningsmæssigt (men ikke nødvendigvis betydningsmæssigt) ufuldstændigt.

En sidste dagligsprogsfilosof der må nævnes i sammenhæng med tekstlingvistikkens alternative fundering, er Grice. Det er netop ham Harder henviser til, og Grices kommunikationslogik angives da også som grundlag for flere senere tekstlingvistiske fremstillinger. Grices pointe er at meningsproduktionen er et samarbejde, og at dette samarbejde strækker sig vidt: Selv når afsenderens ytring ikke umiddelbart ser ud til at give mening, antager modtageren at afsenderen handler rationelt inden for rammerne af et fælles, antaget formål. Her vil modtageren - hvis der ikke er andre grunde til at tro at afsenderen ikke vil samarbejde - forsøge at slutte sig til en mening. For så vidt som Grices udgangspunkt er at vi siger og skriver noget andet end vi mener, må sprogforståelsen i henhold til denne tankegang anses for inferensbaseret. Modtageren inddrager sin viden om situationen og det antagne formål og tilfører information til den sprogligt repræsenterede information ved inferenser baseret på denne viden. Forventningen om formålsrettet adfærd er vel at mærke gensidig: Ligesom modtageren antager at afsenderen handler formålsrettet, antager afsenderen at modtageren handler formålsrettet, dvs. kan og vil lave det forståelsesarbejde, herunder de inferenser, der skal til for at meningen tilvejebringes.

Konsekvensen af at fundere en tekstbeskrivelse på sproghandlingsteorien og kommunikationslogikken er altså: 1) Udsagnet kan ikke anses for at være en meningsmæssig enhed og kan derfor ikke være udgangspunkt for beskrivelsen af hvorledes mening tilvejebringes i sprogbrugen; den minimale meningsbærende enhed er ytringen/ sproghandlingen, og det er således den der må være udgangspunktet for beskrivelsen. 2) Tilvejebringelsen af ytringens mening beror på et samarbejde mellem afsenderen og modtageren under den gensidige 


\section{Simon Borchmann}

antagelse at den anden handler hensigtsmæssigt i forhold til et fælles formål. Modtagerens bidrag til samarbejdet omfatter vidensbaserede inferenser, og afsenderen udformer ytringen under antagelse af modtagerens evne og vilje til at levere dette bidrag. Beskrivelsen af ytringer og ytringers mening må ske ud fra antagelsen om denne rationalitet.

\subsection{Kritik af sproghandlingsteorien som tekstbeskrivelse}

Tekstpragmatikere og tekstlingvister har peget på flere problemer ved sproghandlingsteorien som tekstbeskrivelse. Nogle har anfægtet brugen af konstruerede eksempler (Stubbs 1983, Roulet, 1984). Andre har anført at sproghandlingsteorien betragter sproghandlinger isoleret fra deres sammenhæng (Ferrara 1980) og ikke forklarer hvordan en given mængde sproglige udtryk ytret i en bestemt situation får sin specifikke tolkning (Yule \& Brown 1983, Bazerman 1994). Endnu andre har kritiseret de sproghandlingsteoretiske taksonomier; således bemærker de Beaugrande \& Dressler at der er afgørende forskelle på veldefinerede handlinger som love og true, og ekstremt vage handlinger som hævde, beskrive og spørge. De peger på at dagligsproget er langt mere divergerende og langt mindre gennemsigtigt (end handlinger som 'jeg lover at komme', og 'undskyld.'), og at mange almindelige intentioner stort set aldrig er ekspliciterede. Vi siger ikke, skriver de Beaugrande \& Dressler, "Hermed forsøger jeg at få dig til at gå med på min plan" selv om det er en af de hyppigste intentioner blandt sprogbrugere (1981 (1972):117).

Disse problemer kan imidlertid løses: Man kan anvende autentiske eksempler som grundlag for tekstbeskrivelsen; man kan gå til kommunikationslogikken og/eller den kognitionspsykologisk producerede evidens hvis man vil vide noget om hvordan man når fra det skrevne/ sagte til det mente; og man kan opgive at opstille taksonomier og i stedet - som Swales og Bathia - gå til empirien med henblik på at beskrive enkelte, specifikke genrer eller genrekomponenter (Swales 1990, Bathia 1993). Disse kritikker berører ikke sproghandlingsteorien som den filosofiske teori om sproget generelle funktion og virkemåde den præsenteres som. Man skal således også bemærke at ingen af disse kritikker anfægter den antagelse at den illokutionære handling er den minimale enhed i meningsproduktionen.

Antagelsen om den illokutionære handling som den minimale enhed rejser til gengæld nogle spørgsmål når man vil beskrive tekster. Sproghandlingsteorien har haft sit udgangspunkt i sproghandlinger der realiseres ved en enkelt sætning. Det kan forsvares for så vidt som det er 


\section{Tekster og sproghandlinger ...}

en generel teori om sprogets funktion og virkemåde. Ikke mindst fordi helsætningskriteriet på dansk og en række andre nationalsprog netop er at sætningen realiserer en illokutioncer ramme (Heltoft 1999) og dermed en indikator for hvilken sproghandling der udføres med sætningen. Tekster består imidlertid typisk af sekvenser af sætninger, og derfor rejser der sig umiddelbart følgende spørgsmål for den sprogvidenskabelige tekstbeskrivelse: Skal en tekst betragtes som én sproghandling eller som en sekvens af sproghandlinger?

Svaret er at begge betragtningsmåder er nødvendige for en udtømmende beskrivelse. Antagelsen om at teksten er én sproghandling er nødvendig dels for udformningen af et adækvat tekstkriterium, dels som forklaring på det faktum at tilhørere og læser forsøger at skabe sammenhæng mellem sætningernes meningskorrelater når de præsenteres for en sekvens af sætninger - at de med andre ord behandler en sekvens af sætninger som en helhed. Antagelsen om at teksten er en sekvens af sproghandlinger er - som vi skal se nedenfor - nødvendig for at forklare hvordan læsere kan skabe sammenhæng mellem sætningers meningskorrelater.

I det følgende beskrives det hvilke konsekvenser disse to sproghandlingsteoretiske betragtningsmåder har for henholdsvis tekstkriteriet og redegørelsen for de sproglige betingelser for at skabe sammenhæng. Der sammenlignes med den sprogsystematiske tekstlingvistiks antagelser.

\subsection{Funderingens konsekvenser for tekstkriterierne}

Som Harder påpeger, har den sprogsystematiske tekstlingvistiks tekstkriterier nogle uheldige konsekvenser. Ifølge såvel van Dijks som Halliday \& Hasans kriterier er nedenstående computergenerede sekvens af sætninger en tekst. Den opfylder endog på forbilledlig vis det makrostrukturelle kriterium og kohæsionskriteriet:

John Bear is somewhat hungry. John Bear wants to get some berries. John Bear wants to get near the blueberries. John Bear walks from cave entrance to the bush by going through a pass through a valley through a meadow. John Bear takes the blueberries. John Bear eats the blueberries. The blueberries are gone. John Bear is not very hungry. ${ }^{7}$

Følgende autentiske, formålsrettede og empirisk set velfungerende tekst er derimod ikke en tekst: 


\section{Simon Borchmann}

Hvidovre spiller hjemmekamp torsdag d. 17. Vi skal være ude inden k1. 17.00. Hallen er åben.

$\mathrm{Jacob}^{8}$

Det er utåleligt. Og det er da også uforeneligt med en dagligsprogsfilosofisk funderet tilgang til tekstbeskrivelsen. I henhold til det tekstkriterium Harder formulerer, er det omvendt; den computergenerede sekvens af sætninger er ikke en tekst for så vidt som der ikke er noget kommunikativt formål med produktionen, mens den autentiske sekvens er en tekst for så vidt som den er en formålsrettet handling der udføres via en sekvens af sætninger.

Når sprogbrugere præsenteres for en sekvens af sætninger, forsøger de at skabe sammenhæng mellem sætningernes meningskorrelater; de opfatter altså tilsyneladende sekvensen som noget der udgør en helhed. Denne observation giver anledning til at spørge: Hvis de sprogsystematiske tekstlingvister ikke regner en manifesteret sekvens af sætninger for en tekst, hvordan kan det så være at de gør det de normalt gør i mødet med en tekst, herunder forsøger at skabe sammenhæng? (Vi forsøger jo heller ikke at slå søm i væggen med en sildefilet for så - når det mislykkes - at konstatere at det ikke er en hammer). Svaret kan - i henhold til dagligsprogsfilosofien - kun være at det at noget er en manifest sekvens af sætninger, er tilstrækkeligt til at dette noget opfattes og behandles som en tekst ${ }^{9}$ : Det at sekvensen er manifest, er tilstrækkeligt til at antage at nogen gjort sig den umage at producere den; det at der er tale om sætninger, dvs. noget der ud fra udtryksformen at dømme er manifestationer af den fælles bevidsthed sprogsystemet udgør, er tilstrækkeligt til at antage at de har gjort det med en kommunikativ intention; og det at der er tale om en sekvens, dvs. at sætningerne er anbragt i fysisk nærhed af hinanden, er tilstrækkeligt til at antage at de ligger til grund for en intentionel helhed. Fra en dagligsprogsfilosofisk synsvinkel er det eneste deskriptive tekstkriterium altså: 'En manifest sekvens af sætninger'. Når det er opfyldt, opfatter og behandler sprogbrugere sekvensen som én sproghandling. Det indebærer at sprogbrugeren anvender en række forståelsesstrategier som han eller hun så kan have større eller mindre succes med alt efter hvor hensigtsmæssigt teksten er udformet i forhold til formålet. Succesen beror på tekstens relation til normative kriterier. 
Årsagen til de sprogsystematiske tekstlingvisters performative inkonsistens er at de ikke skelner mellem deskriptive kriterier (hvad tekster er) og normative kriterier (hvad tekster skal); som følge heraf kommer de til anvende de normative (regulative) kriterier uden indse at de dermed forudsætter at de deskriptive (konstitutive) er opfyldt.

\subsection{Funderingens konsekvenser for redegørelsen for sammenhoeng}

En sekvens af sætninger må altså betragtes som én handling. I henhold til sproghandlingsteorien kan en simpel sproghandling analyseres i en illokutionær indikator og et udsagn. Når tekstbeskrivelsen funderes på dagligsprogsfilosofien, rejser sig derfor følgende spørgsmål: Kan sekvensen af sætninger - analogt med sætningen - analyseres i én overordnet illokutionær indikator og ét overordnet udsagnsmæssigt indhold? Og kan man følgelig behandle sætningernes udsagnsmæssige indhold uafhængigt af det illokutionære? Det er netop det van Dijk gør i 1977; ved at udskille det illokutionære indhold som noget der behandles ved en anden proces, mener han at kunne opretholde hypotesen om makrostrukturen som en selvstændig meningsgenererende struktur. Hvad angår forståelsen, kan spørgsmålet altså formuleres sådan: Er det sandsynligt at sprogbrugere afleder det udsagnsmæssige indhold af samtlige sætninger og omsætter det - via makroregler - til et makroudsagn for så først derefter - via sådan noget som en overordnet illokutionær indikator - at relatere den repræsentation der kan konstrueres på grundlag af makroudsagnet til situationen?

I henhold til Wittgenstein og Austin er det end ikke muligt; man kan ikke fastlægge et udsagns sandhedsbetingelser uafhængigt af brugssituationen; for hvert sætningsbåret udsagn gælder det således at det må relateres til situationen og den konkrete anvendelse før det kan relateres til andre udsagn for hvilke der altså gælder det samme. I henhold til Grices antagelse om sprogforståelsen som en inferensbaseret proces er det heller ikke muligt; det at lave det "inferensielle" modsvar til implikaturer fordrer inddragelse af andet og mere end det udsagnsmæssige indhold.

Disse dagligsprogsfilosofiske antagelser er ikke bare luftig filosofi; de er understøttet af observationer af dagligsproglig sprogbrug. Det kan illustreres med følgende eksempel: 
Simon Borchmann

\title{
ORECCHIETTE MED BROCCOLI
}

\author{
$*$ \\ 4 PERSONER \\ $450 \mathrm{~g}$ frisk eller frossen broccoli \\ salt \\ 6 spsk olivenolie \\ 75 g speck eller magert bacon uden svær og skåret i små strimler \\ 2 pillede og finhakkede hvidløgsfed \\ $3 \mathrm{dl}$ mælk \\ $450 \mathrm{~g}$ friske orecchiette (se side 48 og 53) \\ $50 \mathrm{~g}$ friskreven Parmesan \\ friskkværnet sort peber \\ FREMGANGSMÅDE \\ Kog broccolien mør i saltet vand og lad den dryppe af. Hak den \\ meget fint. Varm olien og steg speck eller bacon brunt. Tilsæt \\ hvidløget og steg videre i 1 minut. Tilsæt broccoli og salt og rør \\ så mælken i. Kog saucen under omrøring, til den er glat. \\ Kog imens pastaen i 6 min., eller til den er al dente. Lad den \\ dryppe af og kom den i saucen. Tilsæt den revne ost og lidt pe- \\ ber, bland alt godt og servér. ${ }^{10}$
}

Bemærk udtrykket 'Saucen' i 6. helsætning under fremgangsmåden. Med bestemt form forudsætter afsenderen at meningskorrelatet er tilgængeligt for modtageren på trods af at det ikke har været nævnt i det foregående. Der er altså ikke noget argumentoverlap. Forståelsen er ikke desto mindre fuldstændig uproblematisk for enhver med kendskab til genren og til madlavning. Ud fra sit genrekendskab ved modtageren at formålet med en opskrift er at opbygge en repræsentation af procedure der fører fra udgangspunktet $\mathrm{i}$ form af ingredienserne til resultatet $\mathrm{i}$ form af den færdige ret. Ud fra sit kendskab til madlavning ved modtageren at hvis man koger og hakker broccoli, hælder mælk ved og varmer det op, er man godt vej til at have en sauce. Pointen er nu at sau- 
cen kun er tilgængelig under forudsætning af at den intenderede perlokutionære effekt af de forudgående illokutionære handlinger er opnået. Ud fra observationer at dømme forudsætter afsenderen altså ikke alene at læseren inddrager det illokutionære indhold i forståelsen sætning for sætning, men også at det illokutionære indhold omsættes til konstruktion og forandring af repræsentationen. Da makrostrukturen imidlertid begrænser sig til at processere og relatere udsagnsmæssigt indhold, kan den ikke relatere udsagnet med det singulære udtryk saucen til noget.

Ovenstående eksempel vedrører det globale niveau. Men selv på det lokale niveau forekommer det umuligt at relatere sætningers udsagnsmæssige indhold til hinanden uafhængigt af illokutionære indikatorer og uddybende viden om den situation der henvises til. Det kan illustreres med følgende sekvens:

"Men det er vist skik i småborgerlige hjem, - så vidt jeg da ved - at præsentere. Det har jeg ladet mig fortælle. Og det er altså Stefan Steffensen, den eneste digter vi har haft i Norden siden Sigbjørn Obstfelder, og det er Ole Jastrau - du ved nok, Stefan ham den kompromitterede - anmelderen ved løgnebladet derovre - overløberen - forræderen. - Ja, undskyld, Ole, sådan skal en gæst vist ikke optræde - "

Men Jastrau var allerede i færd med at bukke dybt og ironisk. (Kristensen, Tom. Hoervaerk).

Sekvensen stammer fra en fortællende tekst. En af de fundamentale aktiviteter i forståelsen af fortællende tekst er at skabe sammenhæng mellem de beskrevne handlinger og begivenheder; modtageren skal med andre ord kunne svare på hvorfor-spørgsmål til hver enkelt handling og begivenhed fra begyndelsen til enden (Long et al 1996). Sekvensen repræsenterer to handlinger: Det i anførselstegn angiver hvad én person (Sanders) gør; den efterfølgende sætning angiver hvad en anden person (Jastrau) gør. Jeg antager at funktionelle læsere uden videre kan lave brobygningsinferensen mellem disse to handlinger når sekvensen optræder i den tekst den stammer fra: Jastrau bukker fordi Sanders præsenterer ham; og han bukker dybt og ironisk fordi Sanders præsenterer ham på den måde han gør. For at lave denne helt simple brobygningsinferens må læseren - foruden det udsagnsmæssige indhold - som minimum inddrage alt det følgende: 1) at en af de illokutionære handlinger der udføres med ytringen, er en præsentation, 2) at denne handling hævdes som rigtig, 3) at den måde handlingen udføres på, giver anledning til 


\section{Simon Borchmann}

tvivl med hensyn til om rigtigheden i forhold til normer og værdier blev hævdet med rette, 4) at en anden af de illokutionære handlinger der udføres med ytringen, er en undskyldning, 5) at en af de normativt rigtige reaktioner når man præsenteres, er at bukke, 6) at der er en kontrastiv relation ('men') mellem en udført undskyldning for at en ytring ikke er rigtig, og en normativt rigtig reaktion på den kommunikative handling der er blevet undskyldt for, og 7) at man - når man overdriver en reaktion ('dybt') - kan negere (eller ændre) reaktionens effekt ('ironisk').

Hvad angår den markerede kontrastive relation, skal man især bemærke at den altså ikke relaterer to udsagn, men netop to handlinger. For at etablere relationen må modtageren altså både konstruere en repræsentation af handlingerne, herunder sproghandlingerne ved inddragelse af de illokutionære indikatorer, og vurdere disse handlinger ud fra normer og værdier. ${ }^{11}$

Når hypotesen om makrostrukturer er uforenelig med det dagligsprogfilosofiske grundlag, er det altså ikke blot terminologiske skærmydsler: Med hypotesen bortreduceres de faktorer som dagligsprogsfilosofien netop fremhæver som betingelser for meningsproduktionen. Og som eksemplerne viser, efterlader det hypotesen fuldstændig blottet for forklaringsværdi for selv de mest simple forhold i den dagligsproglige sprogbrug vi kalder tekst.

Ideen om kohæsion som det sproglige grundlag for sammenhæng er ligeledes er uforenelig med en dagligsprogsfilosofisk fundering. Tanken om en umedieret relation mellem en sproglig størrelse i en sætning og en sproglig størrelse i en anden, er i stærkest tænkelige opposition til den kommunikationslogiske antagelse om tilvejebringelsen af mening som et samarbejde. Udveksling af information ved brug af sproglige udtryk foregår - og kan kun foregå effektivt - mellem to rationelle, formålsrettede, samarbejdende parter. Når sprogbrugeren Jacob har udformet sin tekst som han har gjort:

Hvidovre spiller hjemmekamp torsdag d. 17. Vi skal være ude inden kl. 17.00. Hallen er åben.

\section{Jacob}

er det et tegn på at han forstår betingelserne for effektiv udveksling af information og anerkender sine modtagere som rationelle, formålsrettede, samarbejdende agenter, herunder som nogle der er i stand at etablere sammenhæng ved at inddrage deres viden om verden og tilføre 


\section{Tekster og sproghandlinger ...}

information til den sprogligt repræsenterede information ved vidensbaserede inferenser.

Når Halliday \& Hasan er nødt til at afvise at sekvensen er en tekst, er det et symptom på at ideen om kohæsion forudsætter en inadækvat model for kommunikation: Halliday \& Hasans "modtager" er ikke i stand til at inddrage sin viden om verden og tilføre information til den sprogligt repræsenterede information ved vidensbaserede infernser. Det er derfor relationen mellem et sprogligt valg $i$ en sætning og et sprogligt valg i en anden sætning skal være semantisk for at sekvensen af sætninger kan anses for sammenhængende. Det er uforeneligt med kommunikationslogikken.

Fra en sprogvidenskabelig og kommunikationslogisk synsvinkel er det særlig problematisk at fundere tekstbeskrivelsen på ideen om kohæsion fordi den ved ikke at inddrage modtagerens psykologi kommer til at ignorere nogle af de mest centrale sproglige betingelser for at skabe sammenhæng: informationsstrukturen. Det kan anskueliggøres med følgende tekststykke:

Opskåret rødgran i form af tømmer, planker, brædder og lægter anvendes til alle former for bygnings-konstruktioner. Fra fortrinsvis Sverige importeres planker og brædder af rødgran til den danske produktion af tagspær og limtræ. Årsagen til at det ikke er dansk gran, der anvendes til disse produkter, kan være at kvaliteten - både med hensyn til knaster og tørring - ikke er god nok. (52 Trcearter. Træbranchens Oplysningsråd)

Denne sekvens er fuldstændig kohæsiv i henhold til Halliday \& Hasans redegørelse. Fra en kommunikationslogisk synsvinkel er den imidlertid problematisk fordi afsenderen med sine sproglige valg ikke tager hensyn til det forståelsesarbejde modtageren laver. Den rationelle, samarbejdende modtager prioriterer informationen med hensyn til relevans og bruger i dette arbejde afsenderens strukturering af information som indikation på prioriteterne. Modtageren forventer at den relevante information skal findes i fokusdomænet i en umarkeret konstruktion, og med afsenderens placering af 'Fra (...) Sverige' i forfeltet - den umarkerede konstruktions antifokus - kan modtageren i henhold til denne heuristik udelukke at dette er den relevante information i forhold til det efterfølgende. $\mathrm{Nu}$ viser det sig ved læsningen af den tredje sætning at det ikke desto mindre netop er denne information der er den relevante i forhold til det efterfølgende. Således er modtageren nødt til at lave en omkostningsfuld omprioritering af informationen. Og det gør teksten til 


\section{Simon Borchmann}

en mindre vellykket tekst. Sådanne problemer kan man ikke beskrive med udgangspunkt kohæsionsredegørelsen.

Ligeså magtesløs står kohæsionsredegørelsen over for implikaturfænomener. F.eks. det Hamsun udnytter i konstruktionen af fortælleren i følgende tekststykke:

Jeg så engang $\mathrm{i}$ et selskap en ung kvinde forelsket. Hendes øine var da dobbelt blå og dobbelt strålende, og hun kunde slet ikke skjule sine følelser. Hvem elsket hun? Den unge herre borte ved vinduet, husets søn, en mand med uniform og løverøst. Og Gud, hvor hendes øine elsket den unge mand, og hvor hun sat urolig på stolen!

Da vi gik hjem om natten, sa jeg, fordi jeg kjendte hende så godt:

'Hvor veiret er lyst og herligt! Har du moret dig i nat?'

Og for å imøtekomme hendes ønske, trak jeg min forlovelsesring av fingeren og sa videre: 'Se, din ring den er blit mig for trang ... (Knut Hamsun. Ringen).

Som læseren bemærker, foranlediger fortællerens sproglige valg problemer i forståelsen: Fortælleren der i første omgang konfigureres som en ikke-involveret tilskuer til en forelsket kvinde, må siden rekonfigureres som vidne til sin forlovedes svig. Ud fra kohæsionsredegørelsen må vi imidlertid nøjes med at konstatere at der er gennemgående kohæsion for så vidt som 'hende' i ledsætningen 'fordi jeg kendte hende så godt', er en endoforisk "reference" til 'en ung kvinde' i den første sætning. Redegørelsen forskertser dermed muligheden for at beskrive disse to sproglige valgs rolle i forhold til det problem tekststykket foranlediger: Den dramatiserede fortællers valg af ubestemt form på et led i fokusdomænet legitimerer den generaliserede konversationelle implikatur at han ikke har et nærmere kendskab til kvinden (ellers skulle han have valgt et mere informativt valg), og derfor opstår der inkohcerens når vi støder på brugen af 'hende' i ledsætningen 'fordi jeg kendte hende så godt'.

Kohæsionsredegørelsen er ikke bare utilstrækkelig for tekstbeskrivelsen; den blokerer også for en adækvat skrivedidaktik. En af de vigtigste pointer i skrivedidaktikken er at der er en modtager i den anden ende der dels anvender de for skriftsproget karakteristiske indikationer på informationsprioritet, dels antager at afsenderens sproglige valg er så informative som det kræves $\mathrm{i}$ forhold til det antagne formål 
på det pågældende tidspunkt. Ved at dosere at sammenhæng er en rent sprogsystematisk, dvs. ikke kommunikativt medieret, relation blokerer kohæsionsredegørelsen for at lære elever at kommunikation er et samarbejde, og i forlængelse heraf hvad deres del af dette samarbejde består i.

Det skulle nu gerne stå fuldstændig klart at ideerne om makrostruktur og kohæsion er uforenelige med de grundlæggende dagligsprogsfilosofiske antagelser. Hvis man funderer en sprogvidenskabelig tekstbeskrivelse på sproghandlingsteorien og kommunikationslogikken, har man samtidig afskrevet ideerne om makrostruktur og kohæsion; man kan ganske simpelt ikke bruge termerne sproghandling, illokution, samarbejdsprincippet og implikatur meningsfuldt i sammenhæng med disse ideer. The twain shall never meet!

Når det er relevant at udpensle dette forhold som det er gjort ovenfor, er det fordi ideerne om makrostruktur og kohæsion stadig huserer i den sprogvidenskabelige tekstbeskrivelse. Det er ganske vist mit indtryk at man inden for sprogvidenskaben generelt har indset at makrostrukturer og kohæsion er forskningsmæssige blindgyder. Men termerne bliver ved med at optræde i lærebøger om tekster og tekstbeskrivelse. Selv i de tekstbeskrivelser der angiveligt er funderet på dagligsprogsfilosofien. Således bruges termerne makrostruktur og kohoesion af Vagle et al (1993) og Ulbæk (2005), og termen kohcesion bruges af Bulow-Møller (1989) og Jensen (2003). Det skal så tilføjes at der peges på problemer ved termerne ligesom de nogle steder tilpasses; f.eks. fremhæver Bulow-Møller at det er vanskeligt at skelne kohæsion fra kohærens, og Ulbæk undgår behændigt at skrive at ord refererer til ord. Men det forhindrer ikke mindre reflekterede lærebøger i at videreformidle den oprindelige ide i al sin utilstrækkelighed. Således kan man både hos Møller og Lützen læse at ord refererer til hinanden, og at sådanne relationer skaber sammenhæng (Møller 2002:39, Lützen 2004:34).

Afslutningsvis vil jeg med et enkelt eksempel illustrere hvor galt det kan gå når disse to uforenelige tankegange blandes sammen. Eksemplet er Vagle et al's Tekst og kontekst, og det er valgt dels fordi forfatterne netop anvender termerne makrostruktur og kohoesion i forlængelse af en sproghandlingsteoretisk og kommunikationslogisk fundering af beskrivelsen, dels fordi det stadig er en hyppigt anvendt undervisningsbog på danskuddannelsen i Danmark. Jeg vil her begrænse mig til deres beskrivelse af makrostrukturen: 


\section{Simon Borchmann}

Vi vil understrege at en tekst uten makrostruktur ikke er et eksempel på at makrostrukturerne som sådanne ikke finns. Det er bare et eksempel på en inkohærent tekst og dermed ikke en tekst ifølge vår definition.(1993:180)

Proposisjonsbegrepet stammer fra sannhetssemantikken. Innen denne tradisjonen ser man det grunleggende slik at ords betydning kommer fra deres forhold til referenten "ute i virkeligheten". I kapittel 2 avviste vi den lineære kommunikasjonsmodellen fordi den er grunnet på en slik oppfatning om betydning. Allikevel vil vi bruke proposisjonsbegrepet uten å ta med oss det meningsteoretiske grunnlaget. For oss er proposisjon kort og godt en semantisk enhet. (1993:178)

Vi ser altså proposisjonen som den grunnleggende enheten i semantiske strukturer, både på mikro- og makroniveau. Det betyr at når vi kortfattet og dekkende skal beskrive hva en tekst handler om, vil vi gjøre det i form af (makro)proposisjoner. (1993:178)

Makrostrukturerne spiller en stor rolle for våre kognitive prosesser, det vil si tankeprosesser som har med produksjon, forståelse, tolkning, lagring og aktivisering av informasjon å gjøre. (1993:183)

Ovenfor har vi set hvilke problemer der er med disse antagelser; de skal ikke gentages. Det bemærkelsesværdige er at forfatterne selv har en klar fornemmelse af at der aldrig kan komme noget der ligner produktion, forståelse eller tolkning ud af denne gustne reduktion. Og så tilføjer de:

Selvom vi har sagt at makrostruktur er et semantisk begreb, skal vi være oppmerksomme på at pragmatiske forhold også virker inn på denne prosessen. Vår kunnskap om emnet og verden, våre holdninger og normer og hele den sosiale situasjonen spiller inn når vi gjenkaller og resymerer en tekst.(1993:183)

Da makrostrukturen begrænser sig til udsagn og disse udsagn i henhold til deres egen beskrivelse netop er kendetegnet ved ikke at omfatte viden om emnet og verden, holdninger og normer og hele den sociale situation, indebærer det at makrostrukturer ikke kan spille en afgørende rolle for de processer der har med produktion, forståelse og tolkning at gøre. 
Det er ikke så underligt at de elever og studerende der læser disse sekvenser, får problemer med at skabe sammenhæng. Det betyder imidlertid ikke - i hvert fald ikke ud fra de pragmatiske tekstkriterier - at Tekst og kontekst ikke er en tekst. Men det betyder unægteligt at det er en mindre vellykket tekst.

Så galt kan det altså gå.

\section{Udfordringen for den sprogvidenskabelige tekstbeskrivelse}

Vi har set at den sprogsystematiske tekstlingvistiks ideer om makrostruktur og kohæsion er uforenelige med de grundlæggende dagligsprogsfilosofiske antagelser. Derudover har vi set at ideerne som hypoteser mangler forklaringsværdi for den dagligsproglige sprogbrug vi kaldes tekst. Endvidere er det vist hvorledes ideen om kohæsion dels resulterer i en utilstrækkelig og misvisende tekstbeskrivelse, dels blokerer for en adækvat skrivedidaktik. Endelig har vi set hvorledes brugen af ideen om makrostruktur resulterer i en usammenhængende lærebog. På trods af disse forhold anvendes termerne i mange af nyere lærebøger.

Det er ganske vist videnskabssociologisk interessant at to ideer der 1) må anses for tentative hypoteser 2) kort efter deres undfangelse møder sønderlæmmende kritik og 3) kun i relativt begrænset omfang -i forhold til kontraevidensen - er blevet understøttet af evidens, pludselig kan blive anset for etableret viden. Hvorfor det kan ske, skal der ikke imidlertid ikke gives nogen forklaring på her. I stedet foreslås det at vi konsoliderer den dagligsprogsfilosofiske fundering af den sprogvidenskabelige tekstbeskrivelse og dermed afskriver ideerne om makrostruktur og kohæsion. I forlængelse heraf kan man genoptage de spørgsmål som denne fundering af tekstbeskrivelsen giver anledning til, men som er blevet trængt i baggrunden som følge af importen af de ovenfor skitserede ideer.

Lad os altså i overensstemmelse med dagligsprogsfilosofien antage at den minimale meningsbærende enhed er ytringen/sproghandlingen, og at tilvejebringelsen af ytringens mening beror på et samarbejde mellem afsenderen og modtageren under den gensidige antagelse at den anden handler hensigtsmæssigt i forhold til et antaget fælles formål. Det overordnede spørgsmål er så: Hvad er de sproglige betingelser for skabe sammenhæng? Dette spørgsmål giver anledning til at fokusere dels på de illokutionære indikatorer (i bred forstand), dels på informationsstrukturelle valg som indikation på hvilke inferenser der skal laves i den sammenhængsskabende proces. 


\section{Simon Borchmann}

Det spørgsmål man kan stille til den sprogvidenskabelige tekstbeskrivelse er så følgende: Er en tekst en sproghandling eller en sekvens af sproghandlinger? Hvis vi antager at teksten er en handling, hvad er så relationen mellem den globale sekvensbaserede (makro-)handling og de lokale sætningsbaserede (mikro-)handlinger? Disse spørgsmål har vi stillet til nogle udvalgte skandinaviske sprog- og tekstforskere.

\section{Noter}

1 Et ægtepar har væddet en frokost med nogle andre om hvorvidt Calderon var en stor spansk digter eller en portugisisk opdagelsesrejsende. Konen ringer til manden fra biblioteket og siger: 'We will...'.

2 Hvis hævder at der er leksikalsk kohæsion, forudsætter man et leksikon der omfatter al situationel viden.

3 Bathia har i øvrigt formuleret en lignende kritik af Hallidays registerbegreb (Bathia 1993).

4 Denne fremstilling af Harders kritik er i vid udstrækning baseret på Borchmann 2005.

5 Denne fremstilling er baseret på Borchmann 2005.

6 Ved et foredrag i et lille selskab på Aarhus Universitet i 90'erne blev Searle spurgt om hvorvidt det overhovedet var muligt at lave en klassifikation af sprogbrugstyper når der nu ifølge Wittgenstein var et utal forskellige sprogspil, og at nye kunne opfindes. Searle svarede ved først at henvise til Austin der ifølge Searle en gang skulle have sagt: 'Some people say that there is an infinite number of language games, and then they mention seventeen. It's just loose!'. Og dernæst sagde Searle: 'I'm the kind of guy who - if someone says: "that's impossible" - says: "let's do it!"”.

7 Teksten er genereret af computerprogrammet TALESPIN udformet i et AIforskningsprojekt. Gengivelsen stammer fra Gibbs (1999).

8 Seddel på opslagstavle i hallen på Hvidovre Stadion. Afsenderen, Jacob, var cheftræner for atleterne og informerede om at Hvidovres 1. divisionshold spillede hjemmekamp. Når holdet gjorde det, måtte atleterne ikke bruge faciliteterne, dvs. løbebaner o.1. Men de havde så mulighed for gå over i en hal og træne indendørs.

9 Med mindre der altså er tale om sekvenser der ikke produceres med et kommunikativt formål, f.eks. talespin-sekvensen, hvis produktion tjener et forskningsformål, og konstruerede illustrationer som van Dijks Calderonsekvens og Enkvists Carolus-sekvens.

10 Fra kogebogen: Carluccio, Antonio (1997). Pasta. Hockenfeldt.

11 Man kan anføre at eksemplet er udvalgt med omhu; men det berører ikke det faktum at vi ikke kan have en tekstforståelsesmodel der bryder sammen hver gang der optræder et anførselstegn. 


\section{Tekster og sproghandlinger ...}

\section{Litteratur}

Austin, J.L. (1962). How to do things with words. London. Oxford University Press.

Austin, J.L. (1997 (1962)). Ord der virker. København. Gyldendal.

Bazerman, Charles (1994). Systems of Genres and the Enactment of Social Intentions. I: A: Freedman \& P. Medway (red.): Genre and the New Rhetoric. London: Taylor Francis.

Bhatia, Vijay K. (1993) Analysing genre: Language use in professional settings. New York. Longman.

Berge, Kjell Lars (1986). Tekst og talehandlingsteori. I: Norskrift. 49. Universitetet i Oslo:24-63.

De Beaugrande, Robert \& Wolfgang Dressler (1981 (tysk 1972)). Introduction to text linguistics. New York. Longman.

Brown, Gillian \& George Yule (1983). Discourse analysis. Cambridge. Cambridge University Press.

Bulow-Møller, Anne Marie (1989). The Textlinguistic Omnibus. København. Nyt Nordisk Forlag.

Chomsky, Noam (1976). Reflections on language. London. Temple Smith.

Danes, Frantisek (1974). Functional sentence perspective and the organisation of text. I: F. Danes (red.): Papers on Functional Sentence Perspective. Prag. Academia, Publishing House of the Czechoslovak Academy of Sciences.

Diderichsen, Paul (1966 (1935)). Prolegomena til en metodisk dansk Syntax. I: Helhed og Struktur. København. G.E.C. Gads Forlag.

Van Dijk, Teun (1972). Some Aspects of Textgrammars. Haag. Mouton.

Van Dijk, Teun (1977). Text and Context. Explorations in the semantics and pragmatics of discourse. New York. Longman.

Enkvist, Nils Erik. 1974. Några textlingvistiske grundfrågor. I: Tor Hultman \& Ulf Teleman (red.). Språket i bruk. Lund. Liber Laromedel.

Firbas, Jan (1964). On defining theme in functional sentence analysis. Travaux Linguistiques de Prague. Prag. Académie tchécoslovaque des Sciences.

Firbas, Jan (1974). Some aspects of the Czechoslovak approach to problems of functional sentence perspective. I: F. Danes (red.) Papers on Functional Sentence Perspective. Prag. Academia, Publishing House of the Czechoslovak Academy of Sciences.

Gammelgaard, Karen (2003). Tekstens mening - en introduktion til Pragerskolen. Frederiksberg. Roskilde Universitetsforlag.

Harder, Peter (1979). Tekstpragmatik. En kritisk vurdering af nogle principielle og praktiske tilgange til tekstbeskrivelsen, med ansatser til et alternativ. I: John E. Andersen \& Lars Heltoft (red.). Nydanske Studier \& Almen kommunikationsteori, 10-11. Sprogteori og Tekstanalyse. København. Akademisk Forlag. 


\section{Simon Borchmann}

Gibbs, Raymond (1999). Intentions in the Experience of Meaning. Cambridge: Cambridge University Press.

Grice, Paul (2001 (1975)). Logic and Conversation. I: Carol Henriksen (red.) Can you reach the salt? Frederiksberg. Roskilde Universitetsforlag.

Halliday, M.A.K. \& Ruqaiya Hasan (1976). Cohesion in English. London. Longman.

Heltoft, Lars (1999). Hierarki og rækkefølge - skandinavisk ledstilling i funktionel grammatisk belysning. I: P. A. Jensen \& P. Skadhauge (red.) Scetningsskemaet i generativ grammatik. Kolding. Institut for Erhvervssproglig Informatik og Kommunikation, Syddansk Universitet, Kolding:31-62.

Hjelmslev, Louis (1993 (1943)). Omkring Sprogteoriens Grundloeggelse. København. The Linguistic Circle of Copenhagen.

Kintsch, Walther \& Teun van Dijk (1978). Towards a model of text comprehension and reproducation. Psychological Review, 85:363-94.

Jakobson, Roman (1996 (1960)). Linguistics and poetics. I: David Lodge (red.) Modern Criticism and Theory. New York. Longman.

Jensen, Elisabeth Halskov (2003). Tekstlingvistik - ind i teksten. I: Elisabeth Halskov Jensen \& Jenny Anneberg Olesen (red.) Tekstens Univers - en introduktion til tekstvidenskab. Århus. Klim.

Johnson-Laird, Philip. N. (1983). Mental Models. Cambridge. Harvard University Press.

Long, Debra L., Mark R. Seely, Brian J. Oppy. \& Jonathan M. Golding (1996). The Role of Inferential Processing in Reading Ability. I: B. K. Britton \& A. C. Graesser (red.) Models of Understanding Text. London. Lawrence Earlbaum.

Lützen, Peter Heller (2004). Sproglig analyse og relevans. Dansklærerforeningen.

Mathesius, Vilém (1975 (1961)). A Functional Analysis of Present Day English on a General Linguistic Basis. Mouton: The Hague/Paris.

Mukarovsky, Jan. 1964 (1939). Standard Language and Poetic Languages. I: Paul L. Garvin (red.) A Prague school reader on esthetics, literary structure and style. Washington. Georgetown University Press.

Møller, Henrik (2002). Grundbog i tekstlingvistik. Dansklærerforeningen.

Saussure, Ferdinand (1970 (1916)). Kurs i allmän lingvistik. Bo Cavefors Bokförlag.

Searle, John (2001 (1965)). What is a Speech Act. I: Carol Henriksen (red.) Can you reach the salt? Frederiksberg. Roskilde Universitetsforlag.

Searle, John (1996 (1979)). Expression and Meaning. Cambridge. Cambridge University Press.

Swales, John M. (1990). Genre Analysis: English in academic and research settings. Cambridge. Cambridge University Press. 
Togeby, Ole. 1979. Men hva' med kongen. Om tekstlingvistisk analyse. I: John E. Andersen \& Lars Heltoft (red.) Nydanske Studier \& Almen kommunikationsteori, 10-11. Sprogteori og Tekstanalyse. København. Akademisk Forlag.

Togeby, Ole (1993). PRAXT - pragmatisk tekstteori. Århus. Aarhus Universitetsforlag.

Ulbæk, Ib (2005). Sproglig tekstanalyse - introduktion til pragmatisk tekstlingvistik. Århus. Academia.

Vagle, Wenche, Jan Svennevig \& Margareth Sandvik (1993). Tekst og Kontekst. Oslo. Landslaget for norskundervisning. Cappeln Akademisk Forlag.

Vater, Heinz (1992). Einführung in die Textlinguistik. München. Fink.

Wittgenstein, Ludvig (1995). Filosofiske undersøgelser. København. Viborg. Munksgaard.

Simon Borchmann

Nordisk Institut

Aarhus Universitet

norsib@hum.au.dk 